\title{
Moral and Character Rehabilitation of Drug's Victims Through Moral-Spiritual Approach as an Effort to Build a Charactered Citizens
}

\author{
Ahmad Qudsi 1,*, Suwarma Al Muchtar ${ }^{2}$, Prayoga Bestari ${ }^{3}$ \\ ${ }^{1,2,3}$ Universitas Pendidikan Indonesia, Bandung, Indonesia \\ *Corresponding author. Email: ahmadqudsi@upi.edu
}

\begin{abstract}
The Surface problem of this research is the dangerous impact of the drug. The impact of drug use is not only limited to physical damage but also causes moral damage and the character of the drug victim. The morals and character of the Indonesian nation should have been passed on to adolescents but because of the drugs, disappeared and caused other moral problems. Therefore, it is necessary to revitalize moral values and character among adolescent victims of drugs. Not only is physical and mental recovery from drug addiction needed but the morals and character of adolescents also must be recovered. The purpose of this research is to describe the moral and character rehabilitation among adolescent drug victims. This research used a qualitative approach and case study as a research method which the data was collected through interviews, observation, and documentation. Based on the results of research on the moral revitalization and character of drug addicts, it is carried out through a moral-spiritual approach as a means of rehabilitation. This approach can rebuild morality and help drug victims achieve a level of self-actualization to build a society that is under the mandate of Pancasila. In addition, the moral-spiritual approach also shapes the character of the citizen (civic disposition) to become a good citizen. This is an effort to build a citizen with character under the Pancasila ideology.
\end{abstract}

Keywords: Drugs, Moral and Character, Moral-spiritual Approach.

\section{INTRODUCTION}

Drugs are a type of substance that causes dependence and affects the performance and processes of the brain if consumed by humans or animals. The impact of drugs is not only limited to physical damage but also causes moral and character damage to drug victims, especially those of teenagers. In line with that, Setyawati revealed that drugs are dangerous if consumed by humans, not because of the content they have, but the effects caused by their use [1]. The drug problem is a problem that makes all countries in the world worried and restless. The United Nations Office on Drugs and Crime (UNODC) as a world agency dealing with narcotics problems noted that at least 271 million people worldwide or $5.5 \%$ of the global population of the world's population with an age range of 15 to 64 years have consumed drugs, at least the person had consumed narcotics in 2018 [2].

The number of drug victims also occurs among Indonesian teenagers. The national survey of drug abuse conducted by the National Narcotics Agency (BNN) on 13,710 respondents consisting of junior high school, senior high school, and university students in 2013 stated that in the last year there were $3.9 \%$ of respondents who abused drugs [3]. The data above shows that there are many cases of drug use that occur in the community. This means that the number of drug victims is increasing every year and the impact is increasingly felt.

The rise of drug use in this era is a sign of the destruction of a country because the impact of drug use is not only limited to physical damage but also causes mental and moral damage to drug victims. Damage to the mental condition of drug victims also results in damage to morals and character, especially for teenagers. The decline of morals and character under the values of Pancasila ideology among Indonesian youth due to drugs is a very serious problem, because teenagers who are the generation that should be the pillars of the nation's successor and continue the moral and character of the Pancasila Indonesian nation, actually suffer moral and 
character damage as a result because of drug effects. The loss of the morals and character of Pancasila in drug victims is a very serious problem because as the next generation of the nation, the younger generation must understand and practice the morals and character of the Pancasila Indonesian nation. In line with that, Flacks [4] said that drug use among teenagers is a serious problem because drugs also damage the mental and character of teenagers.

Civic education as one of the studies in the social and state fields has a very essential role in improving human quality. Systematically, citizenship education aims to cultivate cognitive, affective, and psychomotor aspects under the moral values and character of Pancasila and the 1945 Constitution as the personality and behavior of the Indonesian people, nation, and state. Odusanya [5] says that making citizens of high morals and responsibility is one of the goals of civic education worldwide.

Civic education has a paradigm that directly carries out its main goal, developing civic competency, namely civic knowledge (knowledge and insight into citizenship), civic disposition (values, commitments, and civic attitudes) [6]. Civic disposition is the character or character of a citizen which is an important competency that every citizen must-have. Branson, (in Diana) says Civic dispositions are orientations related to the formation of civic character. The character of citizens consists of public and private characters that are important for the maintenance and improvement of quality citizens [7].

Ar-Rahman Rehabilitation Center is an institution that uses a psychic and moral-spiritual dimension approach in rehabilitating drug victims. Based on the results of the preliminary study, it is known that the approach is known as the Moral-spiritual approach. This approach is used to rehabilitate the morals and character of victims affected by drugs. The goal is to foster the morals and character of drug victims so that they become human beings who have morals and character (Civic disposition) that are under the Pancasila ideology.

From previous research, it is known that the moralspiritual approach is used by the Ar-Rahman Rehabilitation Center. This approach is used to rehabilitate drug victims to rehabilitate the morals and character of citizens affected by drugs. Based on the description above, the researcher is interested in conducting research.

\section{THEORETICAL REVIEW}

What is discussed is an overview of the moralspiritual approach, an overview of drugs, the theory of adolescent development, the concept of civic education, and the relationship of the moral-spiritual approach to civic education.

\subsection{Overview of Drugs}

The word comes from a foreign term, namely Narcotic which means drug. In Greek it is called narcosis, the word means to put to sleep. In the Big Indonesian Dictionary, drugs are defined as tranquilizers. Lately, drugs are called NAPZA which are materials that consist of psychotropic substances and other addictive substances. Drug use makes a person addicted or dependent because the body receives the wrong message by detecting drugs as a good drug in relieving pain in the body so that when the organs of the body stop using drugs the body becomes dependent and reacts sakaw. "Sakaw is a withdrawal symptom due to the use of putaw (heroin)"

Drug use can affect the mental awareness of its users. This is in line with what Hermanto [8] said that drugs are substances that have addictive properties and can result in physical or mental damage because these addictive substances directly affect human nerves. This is also reinforced by Christopher [9] which states that narcotic substances function to reduce the ability of the brain and attack the central nervous system, causing behavioral abnormalities or causing hallucinations. This addictive substance also causes dependence and causes stimulation in people who use it. Based on the description above, it can be concluded that drugs used as anesthetics or tranquilizers in the health sector are abused. Substances that should be used as sedatives with certain doses and doses in the health sector are misused for certain purposes.

\subsection{Overview of thce Moral-Spiritual Approach}

The recovery method through a moral-spiritual approach is a concept of moral and spiritual improvement through the cultivation of character values in adolescent drug victims. Through the inculcation of these character values, it is hoped that there will be changes in attitudes and morals, and spirituality in adolescent drug victims [19].

The moral-spiritual approach is a method that can maximize a person's self in developing his personality in social life and maintain awareness in one's self of the existence of God Almighty [20]. The way that can be generally used in moral and spiritual development is by communicating and creating an environmental climate that supports moral development so that transfer and cultivation of values and morals can occur in that environment.

\subsection{Overview of the Concept of Citizenship Education}

Civic education is a type of education that encourages democratic attitudes, skills, and knowledge to engage and deal with important public issues and make democracy a way of life. Cogan [10] reveals that civic education is an educational process that has a mission in shaping the character of good citizens, and has skills, intelligence. In 
line with that, Wahab \& Sapriya [11] state that citizenship education is a disciplinary behavior that teaches knowledge to form citizens, become Indonesian citizens who carry out their rights and obligations as citizens. With that, it can be concluded that civic education is of a disciplinary nature that forms a good character based on Pancasila and the 1945 Constitution.

Citizenship education essentially has the aim of forming a civic disposition so that every citizen who has the intelligence and skills of democracy, can be responsible and has dignity under the mandate described in the 1945 Constitution. So it can be explained also in Article 37 paragraph 1 "Citizenship education is intended to shape students into human beings who have a sense of nationality and love for the homeland". In this context, civics education is civic character education. Therefore, there is a need for appreciation of citizenship education, because in turn, it can develop a civic disposition as a child of the nation and an Indonesian citizen.

Based on the description above, civics education is not just knowledge and theory that is taught in schools, but also the application in society and organizations. Aspects of citizenship education in the paradigm that carries directly its main goal, namely developing civic competency, civic knowledge (knowledge and insight into citizenship), civic disposition (values, commitments, and citizenship attitudes).

\subsection{The Relationship between Moral-Spiritual Approach and Citizenship Education}

As we knew that curriculum 2013 in Indonesian carries out the value and character education. In the regulation of the Minister of Education and Culture of the Republic of Indonesia Number 24 of 2016 concerning the basic competencies of lessons in the 2013 curriculum in education and secondary education, it regulates the core competencies that must exist in learning. The core competencies as referred to in paragraph (1) consist of:

- core competencies of spiritual attitude

- core competencies of social attitudes

- core competencies of knowledge

- core competencies of skills

Concerning these core competencies, one of the objectives of the 2013 curriculum implementation is strengthening character education. The Ministry of Education and Culture determines the main values of character that are interconnected with one another, so it needs to be developed as one of the priorities for the strengthening movement in character education. Related to efforts to strengthen character education, civic education becomes a medium or tool to strengthen valuebased characters [21]. Citizenship education which has been placed as a pillar of character education also has values that must be applied in building a national character, which is expected to realize one form of my man in everyday life as students both individually and in groups. society, citizens, and God's creatures [22].

A moral-spiritual approach is an approach used to actualize oneself so that a person can develop his personality in the community and maintain awareness in one's self of the existence of God Almighty. In line with Shields [12] said that the formation of morals and character reflects the character to seek good and right. Moral character is rooted in the basic desire for good. The way that can be generally used in moral and spiritual development is by communicating and creating an environmental climate that supports moral development so that transfer and cultivation of values and morals can occur in that environment [23]. This approach is used to revitalize the morals and character of victims affected by drugs.

Based on the description above, the moral-spiritual approach has a fairly close relationship with civic education, because both aim to develop and revitalize the morals and character of citizens in different scopes.Styles can be applied using the style palette available within the template. To activate it the press $\mathrm{Ctrl}+\mathrm{Shift}+\mathrm{s}$. Apply the style as required based on the content and context. (Please don't highlight your text in yellow.)

\section{METHODS}

This research uses a qualitative approach and case studies as research methods. A case study is a research method to investigate in a focused way an activity, event, stage, program, event, or group of people. A case is limited by time and activity, then researchers studied the overall information by implementing a series of procedures in collecting $\mathrm{d}$ at a top of the appointed time [13].

Participants of the research that the researcher will conduct in qualitative research are officers who are directly related to rehabilitation through a moral-spiritual approach at the Ar-Rahman rehabilitation center. The participants consisted of Moral and Spiritual Guidance Staff, counselors, youth drug victims. Then, the data collection techniques used consisted of interviews, observation, and documentation. The series of data analysis techniques are carried out through data reduction, data presentation, data verification

Data validity techniques need to be done to strengthen the credibility of a research. In this study, the data validity technique was carried out through triangulation. 


\section{RESULT AND DISCUSSION}

\subsection{Result}

Based on the data obtained from the results of research at the Ar-Rahman Rehabilitation Center Palembang, the drug rehabilitation process for ArRahman Palembang was carried out in an integrative way, starting from the medical-biological process and the moral- spiritual development process. In application, it does not necessarily have to be done sequentially but is carried out according to the needs of the fostered child/addict, so that the process can be combined alternately.

The moral rehabilitation and character of drug victims are rebuilt through a moral-spiritual approach. This approach is manifested in the form of Therapeutic Community TC and Spiritual Guidance:

\section{- Therapeutic Community (TC).}

It is a form of simulation of real-life in a residential area. In TC there are various philosophies and norms adopted to form good behavior. Therefore, the Therapeutic Community (TC) that is built is a Therapeutic Community (TC) which contains and is under the values, norms, and morals of the Pancasila ideology.

The Therapeutic Community (TC) method is a treatment that uses a psychosocial approach. Together with other former drug addicts they live in an environment and help each other to achieve healing. The activities in the Therapeutic Community (TC) are designed to help former drug addicts test their beliefs, self-concepts, and wrong behavior patterns and adopt new, more harmonious, and constructive ways of interacting with others.

The purpose of implementing a Therapeutic Community is the occurrence of changes in behavior, emotional development, intellectual development, spiritual and work skills. The results of the analysis carried out showed that there was a change in drug victims after following the rehabilitation process at a rehabilitation center.

The therapeutic Community uses several services that are useful for training and controlling emotional stability, increasing a sense of brotherhood, exercising creativity, relieving stress, learning to understand problems, expressing feelings of dissatisfaction, finding solutions to a problem.

\section{- Spiritual development}

Is coaching that aims to bring back an awareness that exists in humans, about the presence of God in their lives. To maintain this kind of awareness, it is necessary to foster spiritual health for everyone, especially for drug victims, namely people who experience disturbances in life, both physically and psychologically.

This guidance is also carried out to fulfill the spiritual health of drug victims. One of the characteristics of spiritual health is the desire to find meaning and purpose in life, as a very deep personal appreciation, of the cosmic nature and natural forces that can be used as positive energy for its strength. This positive power, which then becomes the basis for the formation of one's beliefs. This process can maximize a person's self in developing his personality in social life.

The spiritual aspect is fostered through reading scriptures, providing religious knowledge, dhikr, cults, and other worship activities. The purpose of this activity is to develop the spirituality of drug victims to become faithful and pious.

\subsection{Discussion}

The moral-spiritual approach in practice is implemented through the TC method or therapeutic community and the spiritualization process by inculcating religious values and religious norms as an effort to shape morals and good character in drug victims.

The therapeutic community (TC) method has an important role in shaping the morals and character of drug victims. According to $\mathrm{KH}$, the therapeutic community method is a treatment that is built together with other former drug addicts, they live in an environment and help each other to achieve healing. The activities in the therapeutic community are designed to help former drug addicts test their beliefs, self-concepts and incorrect behavior patterns and adopt new, more harmonious and constructive ways of interacting with others. At the Ar-Rahman rehabilitation center, TC instills values, discipline, tolerance, honesty, independence, friendliness/communicative, social care, and responsibility.

The spiritualization process is carried out through cult seminars and religious activities such as dhikr, prayer and other worship. According to data obtained from interviews with $\mathrm{T}$ and $\mathrm{H}$, the spiritualization process is carried out by teaching education about religious basics, requiring congregational prayers, dhikr and guidance on reading the Koran. According to $\mathrm{T}$, remembrance is carried out in three stages, namely verbal remembrance, heart remembrance, and deed remembrance.

Facts in the field based on the results of observations, it is known that a moral-spiritual approach is used to improve the attitudes and behavior of drug victims through moral and spiritual development which is manifested in the form of therapeutic community and spiritual processes by instilling religious values and religious norms through worship activities such as dhikr and worship. then carried out continuously every day so that it becomes a culture for drug victims. The 
implementation is fostered by the following staff, namely: the moral development process which is fostered by the general staff of pruning bad behavior, then the spiritual process which is fostered by the spiritual guidance staff. The therapeutic community method and this spiritualization process synergize to build moral and good character in drug victims as a manifestation of a moral-spiritual approach [14].

Rehabilitation aims to eliminate the adverse effects and recovery of both physical and social function due to drug abuse. According to Article 54 of Law Number 35 of 2009 concerning Narcotics, efforts to recover and prevent drug relapse are carried out through a rehabilitation process, both medical rehabilitation and social rehabilitation [25]. Medical rehabilitation aims to eliminate the effects of physical dependence due to drug addiction through integrated treatment. The moralspiritual approach aims to restore optimal social functioning for victims of narcotics abusers [15]. There is a lot of methods have been developed in an effort to rehabilitate victims of drug abuse, including the Therapeutic Community (TC) program. The theory that underlies the Therapeutic Community method is a behavioral approach that applies which functions to change a behavior, through the cultivation of values and morals, where a group is used as a medium to change a behavior.

The TC method is a recovery method without the use of drugs in therapy. Sociologically, this method is considered to be able to help overcome addiction to addictive substances. In this TC method, drug abusers will learn to face problems, understand and apply values and norms to shape the morals and character of drug victims [26]. The main purpose of the TC method is to restore the moral and character of drug victims and prevent drug relapse, so that drug victims can return to social life in the community. Several studies have stated that the TC method is more effective in preventing relapse of drug abusers after rehabilitation. In line with what Ardani [16] said that the use of therapeutic community methods has high success as a method of recovering drug victims and also functions as a deterrent to relapse. The formation of good morals and character will also create good behavior, as Thomas [17] said, morals require three interrelated categories, namely moral knowing, moral feeling and moral action. Moral refers to a habit of someone who is carried out continuously and likes to do a socially caring behavior. That way drug victims will be directed to become moral people who have the ability to adapt in social life [18].

\section{CONCLUSION}

The process of moral and character rehabilitation of drug victims at the Ar-Rahman Islamic Boarding School in Palembang's Narcotics Rehabilitation Center carried out a moral-spiritual approach, manifested in TC and Religious Guidance:

- Therapeutic Community (TC).

$\mathrm{TC}$ is a real-life simulation in a container to make good behavior.

- Spiritual Development

The spiritual aspect is fostered through reading scriptures, providing religious knowledge, dhikr, cults, and other worship activities.

Through the two things above, there is the inculcation of values, morals, and norms under the Pancasila ideology and reshape drug victims into citizens with character. Through the cultivation of values, norms, and morals that is done it is the character of citizens reshaped, so moral and behavior on the drug victim a better.

The moral-spiritual approach is an approach used in improving the attitudes and bad behavior of drug victims on the basis of moral development and spiritual strengthening as a rehabilitation effort. This approach is manifested in the therapeutic community (TC) method and spiritual process by providing an understanding of religious values and norms, dhikr and worship processes that are carried out continuously every day. This approach has positive implications in increasing civic disposition or citizenship character that must be possessed by drug victims as citizens.

\section{ACKNOWLEDGMENTS}

We thank the Universitas Pendidikan Indonesia and the 3rd Annual Civic Education Conference "Civic Education in Pandemic Covid-19: Challenges and Responses" for support.

\section{REFERENCES}

[1] Setiyawati, et al, Buku Seri Bahaya Narkoba Jilid 1, Surakarta: PT Tirta Asah Jaya, 2015.

[2] BNN, "World drugs report 2019," press release

[3] Haryadi, Rudy, "Prospects of Community Counseling for Individuals Ex-Drug Addicts (Study at a Post-Drug Rehabilitation Institute in Semarang City)," Jurnal Raden Intan, 2018

[4] Flacks, S, "Dangerous drugs, dangerous mothers: Gender, responsibility and the problematization of parental substance use," Critical Social Policy, 39(3), 477-497, 2019, pp. 477-497. https://doi.org/10.1177/0261018318795573

[5] Odusanya, S. P., \& Oni, A, "Civic Education and Pupils' Civic Dispositions in Ghana and Nigeria: A Comparative Analysis," Journal of Education and 
Research, 9(1), 13-27, 2019, pp. 13-27. https://doi.org/10.3126/jer.v9i1.28790

[6] Maiello, C., Oser, F., \& Biedermann, H, “Civic Knowledge, Civic Skills and Civic Engagement. European Educational," Research Journal, 2(3), 384-395, 2003, pp. 384-395. https://doi.org/10.2304\%2Feerj.2003.2.3.5

[7] Diana, "Political Knowledge and the Development of Civic Dispositions and Skills," APSA Preprints, 2020.

[8] Hermanto, Manajemen Layanan Rehabilitasi Korban Penyalahgunaan Narkoba di Panti Sosial Pamardi Putra "Sehat Mandiri, Yogyakarta" Disertasi Doktor pada Sekolah Pascasarjana UGM, 2009.

[9] Christopher, D. Ringwald, The Soul of Recovery: Uncovering the Spiritual Dimension in the Treatment of Addictions, Oxford: Oxford University Press, 2002.

[10] Soemantri, M. Numan, Mengagas Pembaharuan Pendidikan IPS, Bandung: Rosdakarya, 2001.

[11] Wahab, Abdul Azis \& Sapriya, Teori Dan Landasan Pendidikan Kewarganegaraan, Bandung: Alfabeta, 2011.

[12] Shields, D. L, "Character as the Aim of Education," Phi Delta Kappan, 92(8), 48-53, 2011, pp. 48-53. https://doi:10.1177/003172171109200810

[13] Creswell, J. W., "Research Design: Qualitative and Quantitative Approaches". Thousand Oaks, CA: SAGE Publications, 2010.

[14] Chong, J., \& Lopez, D, "Predictors of Relapse for American Indian Women After Substance Abuse Treatment" Journal of The National Center , 14 (3), 24-47, 2008.

[15] Hatcher, J. A., "Defining the Catchphrase: Understanding the Civic Engagement of College Students" Michigan Journal of Community Service Learning 16(2):95-100, 2010.

[16] Hawi, Akmal, "Remaja Korban Narkoba: Studi tentang Rehabilitasi Integratif di Pusat Rehabilitasi Narkoba Pondok Pesantren Ar-Rahman Palembang" journal raden intan 16(2):95-100, 2018.

[17] Hildebrand, C. Educating for British values: Kant's philosophical roadmap for cosmopolitan character education. Policy Futures in Education, 2016 pp. 20-37. http://doi:10.1177/1478210316680766.

[18] Howard, R. W., Berkowitz, M. W., \& Schaeffer, E. F., Politics of Character Education, Educational
Policy, 2004, pp. 18(1), 188-215. DOI: http://doi:10.1177/0895904803260031

[19] Ibrahim, F., \& Kumar, N., Factors Effecting Drug Relapse in Malaysia: An Empirical Evidence, Asian Social Science, 2009,

[20] Jones, C. Character, virtue and physical education. European Physical Education Review, 2005, pp. 11(2), 139-151. doi:10.1177/1356336x05052893

[21] Leininger, M. M., Caring; an Essential Human Need: Proceedings of Three National Caring, Wayne Stat. Michigan, 1981.

[22] Liao, C.-C, Double-Sided Occluded Chinese Character Recognition Accuracy and Response Time for Design and Nondesign Educational Background, SAGE Open, 2018, pp. 8(4), DOI: http://doi:10.1177/2158244018810065

[23] Owen, D., Political Knowledge and the Development of Civic Dispositions and Skills, APSA Preprints. 2020, pp. doi: 10.33774/apsa2020-lqdkw.

[24] Pocetto, A. T. (2014). Positive Psychology, Francis de Sales and Character Formation. Studies in Religion/Sciences Religieuses, 2014, pp. 43(4), 575-591. http://doi:10.1177/0008429814550967

[25] Wagner, L., Good Character Is What We Look for in a Friend: Character Strengths Are Positively Related to Peer Acceptance and Friendship Quality in Early Adolescents, The Journal of Early Adolescence, 2009, pp. 29-50 DOI: http://doi:10.1177/0272431618791286

[26] Talbert, C. H., Matthew and Character Formation, The Expository Times, 2009, pp. 121(2),53-59: DOI: https://doi:10.1177/0014524609345051 